\title{
'Professionalism' in English as a Foreign Language Teachers' Perspectives: A Qualitative Study in a Thai Context
}

\author{
Anchalee Jansem ${ }^{1}$ \\ ${ }^{1}$ Faculty of Humanities, Srinakharinwirot University, Thailand \\ Correspondence: Anchalee Jansem, Faculty of Humanities, Srinakharinwirot University, Sukhumvit 23, Bangkok, \\ 10110 Thailand
}

Received: January 13, 2020

Accepted: February 7, 2020

Online Published: February 8, 2020

doi: $10.5539 /$ elt.v13n3p1

URL: https://doi.org/10.5539/elt.v13n3p1

\begin{abstract}
This study presents the meanings, attributes, and roles of 'professionalism' synthesized from 20 Thai EFL teachers' perspectives. Qualitative research methods were utilized to collect four sources of data including classroom observation transcripts, semi-structured interview transcripts, on-line discussion entries, and field-note recordings. The findings indicated that professionalism refers to the big picture of exemplar, effective teachers. Proficient English skills with an emphasis on oral communication, lesson planning abilities, lesson delivery skills, and commitment to successful student learning were believed to form professionalism which, also, plays multi-roles in teaching.
\end{abstract}

Keywords: professionalism, EFL teachers, perspectives

\section{Introduction}

During the last 50 years, the field of teacher education, including teacher development, has faced many challenges. At the beginning, a significant aspect of the challenges was related to an urge to develop teachers to become ideal professionals (Etzioni, 1969). Since then, a number of educational reforms have been launched, and these reforms have also influenced the way the public views professional teachers. At present, the concept of professionalism is believed to be a fundamental framework in education. However, to pinpoint what professional teachers are or what professionalism is seems to be a difficult task. That is to say, identifying what teacher professionalism is becomes an endless task.

As Stronge and Tucker (2000) argued, effective teachers play the most significant roles in enhancing the quality of student learning. To be effective, the teacher needs to demonstrate professional teaching. Likewise, professional teaching completely associates with how the teacher exhibits professionalism. Yet, so far, the typology of a professional teacher or professionalism has never been introduced by teachers themselves. Instead, scholars, consortiums, associations and other organizations of related fields tend to have power to define the term "teacher professionalism" and "professional teachers" in various ways. Such diverse definitions and components leave room for uncertainty about what teacher professionalism really is. Also, the definitions tend to be broad rather than specific. Due to varying definitions and characteristics of teacher professionalism, paucity of voice, dearth of particular components of professionalism in specific content areas, and limited amount of research in professionalism in teaching English as a foreign language (EFL) context, there is drive to examine the concept of professionalism in teachers' perspectives. In short, the overarching questions that guided this study included:

1) What are the meanings and attributes of professionalism from Thai EFL teachers' perspectives?

2) For Thai EFL teachers, what are the significant roles of professionalism in their careers in teaching?

\section{Literature Review}

Well known scholars and researchers in education have proposed descriptions of the concepts and characteristics of professional teachers. For example, Evetts (2009) compared and contrasted organizational and occupational forms of professionalism. While organizational professionalism involves standardization through managerial controls, occupational professionalism shed light on practitioners'self control and expectations as well as internal authority among the members of each occupational discourse. 
Additionally, Evans (2011) posits that professionalism comprises behavioral, attitudinal, and intellectual components. Evans argues that values, perceptions, and beliefs relate to a teacher's attitude which concurrently dictates behavior. Interestingly, Stronge's (2002) proposed attributes, behaviors, and attitudes of effective teachers. These can be categorized into prerequisites of effective teachers that include carrying out being a teacher as a person, possessing classroom management and organization skills, managing and implementing instruction, and monitoring student progress and potential. Additional three statements that Stronge summarizes also emphasize the similarities of how professionalism is viewed. He states that effective teachers recognize the complexity of teaching, communicate clearly, and devote themselves to the teaching profession through conscious services. To illustrate the range of professionalism, Tichenor and Tichenor (2005) proposed a continuum with one end as the basic level and the other as the highest. While the basic point of professionalism deals with the status of a person who teaches and receives payment, the other end involves the performance to reach the highest standards or expectations. According to Hargreaves (2000), professionals are believed to go through four phases of development of teacher professionalism. The first phase is called the pre-professional age; teachers are controlled by managerial and technical work. The second phase can be viewed as the autonomous professional age with teachers having autonomy to make decisions on curriculum development. The third phase, or the collegial professional age, highlights the development of professional communities. The last phase is perceived as the post-professional age formed when teachers start critically questioning what professionalism really means.

In addition to the complexity of what professionalism really means, what counts as professional teachers, and what stages teachers have been through, other factors have come into play. These factors result in more complexities in defining professionalism. Major influential factors include government, policy, the teaching profession, and social change (Goepel, 2012). Due to the increasing influence of external forces, it can be clearly seen that teacher professionalism carries two different notions. The first notion deals with how professionals define themselves based on their own power and agency. The other, in contrast, deals with the perceptions of being imposed by external constraints (Gleeson \& James, 2007; Hoyle \& John, 1995). Political power and administration can be viewed as external power that shape the concepts of professionalism (Evans (2011).

To illustrate forms of professionalism, Johnson (1997 cited in Gleeson \& James, 2007) noted that while traditional, functionalist perspectives emphasize the shared attributes within each occupation and the functions when giving services, ideological perspectives prefer establishing a monopoly of each profession. Functionalist models identify sets of required skills, knowledge, and code of conduct as the elements of professionalism. In contrast, ideological models highlight the self-interest of professionals to establish occupational dominance.

In the field of education, especially requirements for effective teachers as influenced by a number of factors, lists of qualities for professional teachers have been introduced. To start off, Shulman (1987) proposed the importance of knowledge base of professional teachers. The seven types of essential knowledge include knowledge of subject matter, general pedagogy, learners, educational ends, curriculum, school contexts, and the implementation of pedagogy based on the particular content area. In accordance with professionalism, standards have also played a powerful role. For example, as identified in the Australian Professional Standards for Teachers, (Board of Studies, Teaching and Educational Standards NSW, 2012,p. 4) teachers are required to have professional knowledge, professional practice, and professional engagement: know students and how they learn, know the content and how to teach it, plan for and implement effecting teaching and learning, create and maintain supportive and safe learning environments, assess provide feedback and report on student learning, engage in professional learning, and engage professionally with colleagues, parents and the community . Almost all standards serve as guidelines and frameworks for teacher education programs, for both pre-service and in-service teachers.

In the past, teachers or practitioners' voices were inhibited in teacher education policy making. Gitlin and Meyer (1993) noted that teachers lacked opportunities to be part of the directions of teacher education. However, since the empowerment of teacher agency, teachers' voices have received attention. Note that, so far, scarce research has revealed how teacher perceive the concepts of professionalism. A study in England on this issue has revealed that both defining the term and identifying the components of professionalism are difficult due to the complexities of several factors (Swann et al., 2010). These include teachers' beliefs, dedication, self efficacy, and opinions about how the public recognize teachers. A study in Romania revealed that professional teachers need to possess advanced content knowledge, have professional freedom, and, in the meantime, maintain the alignment with professional standards (Popa \& Acedo, 2006).

Based on another study in England, teachers were found to believe that professional standards are proposed by the government to control teaching practices rather than teachers' knowledge (Evans, 2011). Similarly, Torres-Rocha (2019) critically suggested that professionalism be perceived from a democratic lens. While requirements, standards, and any criteria are used as indicators of professionalism, teacher's identity situated 
locally should be respected too. To empower both sides, tensions can be minimized. In the same vein, beliefs tend to be the one of the most influential factors that affect teaching quality and professionalism. Beliefs also interweave with conceptions that teachers hold. Another study presented Taiwanese teachers' perceptions of professional roles and concluded that the teachers focused on professional roles (Hung \& Li, 2017). They accepted the values of autonomy, knowledge, ethics and teaching competence when serving their teaching. The concept of professionalism promoted by organizational and any form of political groups did not seem to grab their attention. Hence, an understanding of teachers' opinions should be the preliminary stage when considering teacher professional development (Richards et al., 2001). In response to the significant role of teachers' thinking, this study emphasizes the conceptions of professionalism in teachers' perspectives.

\section{Methodology}

To determine how Thai EFL teachers perceive the term professionalism, both the meanings and its significant roles, this study utilized qualitative research methods. Emic perspectives were used in this study as the guideline for both examining and interpreting the participants' perceptions in that specific culture (Coulacoglou \& Saklofske, 2017). As Chapman and Kinloch (2011) argue, an attempt to understand the participants' points of view in their specific, localized contexts conforms to emic perspectives. In this study, Thai teachers teaching English were the participants, and their perceptions of professionalism were curated and documented in naturalistic scenarios.

Twenty Thai teachers teaching English at five different schools in Bangkok, Thailand agreed to take part in this study. Their teaching experience ranged from 5 to 31 years. Other qualifications used to recruit the participants included having an educational background in either English or English Education, being tenured teachers, and teaching in either secondary or primary schools. With qualitative research as paramount, four data collection methods included classroom observation, semi-structured interviews, on-line discussions, and field-note recordings. Each participant was observed and video-recorded four times, via non-participant observation in naturalistic environments. Hence, the total number of observed sessions was eighty. In addition to videotaping, the researcher recorded key events and extraordinarily miscellaneous circumstances in field-notes. At the completion of each observation, the researcher conducted a semi-structured interview with the observed participants. In addition, all participants were encouraged to join an online discussion group via line group. These four methods of data collection yielded qualitative/emic data. The researcher gathered legitimate information for the subsequent analysis. The emic data in this study included the captured events, perceptions, and behaviors that led to the conclusion of how Thai teachers viewed the concept of professionalism (Chapman \& Kinloch, 2011). These multiple sources of data ensure the trustworthiness of the study (Creswell, 1998).

Data analysis started from transcribing all classroom observation videos and the participants' recorded interview responses. Later, the field-notes were sorted, and online group discussion messages were retrieved. Open-coding was used as the major method for data analysis (Strauss \& Corbin, 1990). All four sources of data were managed based on open coding divided into four stages. During the first stage, both verbal and nonverbal behaviors in the transcripts derived from classroom observations were labeled. Similarly, the transcripts of interview responses were labeled. This similar technique was also applied when coding the field-notes and the online discussion transcripts. For the second stage, all labels were grouped. The third stage dealt with comparing and contrasting all labels. The last stage was renaming the labels with the assumption that all labels reflected answers to the research questions.

\section{Findings and Discussion}

\subsection{The Meanings of Professionalism}

All 20 participants' teaching behavior, comments via online chat board, and interview responses were treated as both the platform and data to crystallize how they perceived and defined the concept of professionalism. They realized that the meanings of professionalism reminded them of what 'good' teachers are supposed to do, to teach, and how to live their lives.

Principal meanings of professionalism were crystallized from all participants' 3 different modes including teaching, sharing, and voicing are as follows:

\section{the combined exemplary qualities of being an effective teacher}

outstanding abilities that the teaching community agrees upon

teaching abilities that are beyond general expectations

how an individual teacher applies exemplary teaching skills to enable students to communicate in English 
the state of having, doing, and thinking that is viewed as what a good teacher is supposed to do to effectively teacher students

what a dedicated teacher does and has to do to help students succeed in learning English

The cornerstone of the meanings of English teacher professionalism above seemed to be a state of having interwoven ability, value, and commitment to performing multi-tasks of teaching. Most participants admitted that the concepts of teacher professionalism seemed to be too complicated to describe.

The word 'ability' perceived by the participants in this study seemed to be a prerequisite quality when discussing professionalism. When asked directly what they thought professionalism was, they all mentioned the word 'ability'. The array of defining ability mainly included teaching ability, an ability to motivate and inspire students, and being able to switch roles when needed. For example, Teacher A believed that professionalism and professional teacher coincided, meaning "an ability to teach resulting in students' proficiency English skills". Similarly, Teacher B focused on an ability to manage teaching and learning skillfully, leading to students' English improvement and better attitudes toward the English language.

\subsection{The Attributes of Professionalism}

In addition to the meanings of professionalism concluded in the previous section, the scope and components of professionalism also appeared in participants' perceptions, reflections, and teaching behaviors. As such, all participants illustrated definitions of professionalism via these attributes. Both the simplicity of interviews as well as discussion responses and the complexity of underlying beliefs that shaped their teaching practices reflected what they thought would form professionalism. The attributes of professionalism proposed by all participants were grouped into knowledge of English language, lesson planning skills, lesson delivery techniques, and commitment to student learning.

\subsubsection{Knowledge of English Language Knowledge}

Teachers in this study seem to have a consensus that English language knowledge is a preliminary element or gateway to professionalism. In each interview, all of them commented on the necessity of deep knowledge and proficient skills. Deep knowledge in participants' perspectives refers to language accuracy. As one teacher said, "a professional English teacher could be viewed as an agent of English user." Hence, the teacher's English knowledge must be sufficient for both modeling how to use it and how to transfer it to students. Among all areas of the English language, oral communication skills received an emphasis. As almost all teachers agreed, "to enable Thai students to speak English, the teacher needs to be highly proficient, especially speaking and listening." In doing this, advanced skills in speaking were highly needed, especially during the booming period of the communicative approach.

\subsubsection{Lesson Planning Skills}

Based on both interview responses and comments shared via online discussions, lesson planning skills are believed to be a quality of professionalism which refers to the ability to plan an effective lesson. To the majority of teachers in this study, lesson planning might look simple, but it took time and effort. Teacher professionalism would not be fulfilled without specific knowledge and skills to plan a series of well-prepared lessons. A teacher argued in an on-line discussion that lesson planning required refined ability in selecting appropriate learning materials, choosing suitable teaching strategies, and creating supportive learning environments. Lesson planning requires weaving all related areas of knowledge and experience ranging from knowledge of curriculum to assessment and educational innovation.

\subsubsection{Lesson Delivery Techniques}

One criterion used to differentiate teachers based on the degree of professionalism is lesson delivery techniques. All participants agreed upon the importance of teaching and believed that the quality of teaching in the classroom reflected the actual dimension of professionalism. For them, professionalism is embedded with how well the teacher could enable students to succeed in learning English. To achieve the benchmark of professionalism, the teacher needed to integrate effective teaching strategies, appropriate classroom management, appropriate communication styles, and techniques to motivate and inspire students. Delivery techniques in all teachers' perspectives did not need to completely conform to theories. Instead, the teacher needs to realize all factors associated with the lesson. As a teacher mentioned in her online responses, "Professionalism unavoidably comprises professional practices during any lesson." 


\subsubsection{Commitment to Student Learning}

The last attribute of professionalism that teachers in this study took into account is the teacher's commitment to student learning. That is, only knowledge and teaching skills would not guarantee a teacher meeting the concept of professionalism. Instead, dedicated teachers who always guided themselves to take care of all tasks related to lifting the quality of teaching and learning would fit the concept of professionalism. As 6 teachers shared via their comments, professionalism must include willingness and desire to carry out teaching with pride. With commitment, teachers would attempt not only to perform teaching tasks seriously but also look forward to improving work quality. Commitment, as some participants argued, was based on an individual's view of dedication, not job requirements. "Teacher commitment is similar to the realization of working for the betterment of students, not the teacher, said a teacher. Others also shared similar thoughts that commitment must be self-driven.

\subsection{The Roles of Professionalism}

According to all teachers in this study, the roles of English teacher professionalism in Thai schools seemed to vary, depending on how each teacher regarded professionalism. Four major roles appeared in this study. Firstly, for those who had clear pictures of what professionalism was and had strong desire to conform to the notion of professionalism, the role of professionalism was a mission. The mission reminded them of what they were supposed to do and not to do. These teachers would always take professionalism into account, setting high expectations for students, themselves, and the teaching profession. Secondly, for teachers who treated teaching as a career based on their belief that they had both knowledge and interests in transferring English knowledge and skills, professionalism was a set of expectations. They accepted that students and parents would prefer skillful teachers that would enable students to succeed in learning English. Thirdly, for teachers who were not certain about the notion of professionalism, the role that professionalism played was just an ideal concept. As an ideal concept, some teachers were concerned that it was somewhat too difficult to reach. They accepted the value of professionalism. However, due to the lack of some qualities, to meet professionalism requirements seemed to be inhibited. Lastly, most teachers viewed professionalism as a measure for accountability. In an on-line discussion with more than 40 entries, the main part of the content was that teachers should be responsible for their tasks. Other teachers who had similar idea said that one simple way to display accountability in education in order to receive trust from the public is the vivid roles of professionalism. Two teachers added their critical viewpoints that English teachers in Thailand deserved scrutiny due to complaints that Thai students' English proficiency tended to be too low. When the public challenged the quality of teaching and learning English, teacher professionalism cannot avoid being scrutinized.

\section{Discussion}

The findings in this study revealed that all participants generally have their own perceptions about teacher professionalism. While it has been discussed that the definitions of professionalism vary, the EFL teachers in this study, surprisingly, expressed similar viewpoints. For the meanings of professionalism, they mainly focused on abilities, qualities, and effective teaching. Compared to the components of professionalism including behavior, attitude, and knowledge discussed by Evans (2011), the term professionalism for Thai EFL teachers seem to comply to all. That is, they believed that abilities are the outcomes of the interplay between behavioral and intellectual qualities, and effective teaching would be the catalyst of all.

Englund (1996 as cited in Hargreaves, 2000) noted that teachers generally view professionalism as either what they do or what controls their actions. The definitions shared by the teachers in this study are aligned with the former. It is likely that they emphasized the quality of teaching with knowledge, skills, and values as the foundations of effectiveness. Hence, it can be assumed that, based on the participants' beliefs, the concrete state of professionalism is expressed through the teacher's intellectual, behavioral, and attitudinal qualities. Not surprisingly, teaching practices and comments the participants shared in discussions reflected these assumptions of professionalism.

The findings also showed the elements of professionalism as perceived by the participants. As EFL teachers, the participants regarded knowledge of English language, lesson planning skills, teaching techniques, and commitment to student learning as core attributes. These tend to be in accordance with subject matter, general pedagogy, and pedagogical content knowledge (Shulman, 1987). The four attributes also relate to foundation and application domains used as indicators of TESOL professionalism (Kuhlman \& Knezevic, n.d). It is likely that the participants' perceptions about professionalism were shaped by an idea of what practitioners are supposed to do when performing teaching. They leaned toward traditional, functional perspectives (Johnson, 1997 cited in 
Gleeson \& James, 2007) that required skills and code of conduct of a particular occupation to shape professionalism, rather than ideological perspectives that value self-interest.

The other part of findings present the roles of professionalism. All four roles in the participants' beliefs including a mission, a set of expectations, an ideal concept, and a measure for accountability expressed in this study emphasized their significant notion of professionalism. It can be implied that the multiple roles would influence the participants' teaching practices. A set of expectations and an ideal concept might serve as a soft version of standards and obligation. However, no participants mentioned government or any other organizational controls, or even occupational freedom. It can be assumed that global/local tensions (Torres-Rocha, 2019) was not a major concern for the participants. The role of professionalism as a mission could mean they agreed upon the influential status of teacher professionalism within the insiders' value rather than obligations from outsiders.

The combination of the findings in this study also leads to a further discussion on the development of teacher professionalism. Based on Hargreaves's (2000) four periods of teacher professionalism, the meanings, attributes, and roles of professionalism shown in this study seem to be mainly situated in the age of the autonomous professional. They focused on justifying each teacher's intellectual and teaching skills independently. In doing this, they might feel free to isolate themselves or did not realize the existence of the teaching community. Their interests would be just their success in teaching and student learning. As such, 'strong professional cultures of collaboration' (Hargreaves, 2000, p. 15) did not appear in the participants' perspectives.

The findings in this study were limited to 20 participants in specific contexts. Other contexts of studies might yield different notions of professionalism. To justify the meanings, attributes and roles of professionalism voiced by the EFL teachers is beyond the purposes of this study. Also, though trustworthiness of qualitative research was employed during data collection and analysis, the findings are mainly based on the research's interpretive lenses. These all could be viewed as limitations of this study.

\section{Conclusion}

To conclude, this study uncovered the meanings, attributes, and roles of teacher professionalism based on 20 Thai TEFL teachers' perspectives. The findings indicated that professionalism refers to the big picture of exemplar, effective teachers. To conform to the concept of professionalism, the participants believed that teachers needed to possess proficient English skills with an emphasis on oral communication, lesson planning abilities, lesson delivery skills, and commitment to successful student learning. Professionalism also played various roles, ranging from being a mission, a set of expectations, an ideal concept, and a measure for accountability. The EFL teachers who shared their voices in this study were aware of professionalism. This could serve as information for teacher educators to realize how EFL teachers viewed the status of professionalism. Likewise, educational policy makers may utilize the information when planning professional development and curriculum development policies.

\section{Acknowledgements}

This study was funded by the Faculty of Humanities research grant 394/2558. The author would like to thank the all teachers who voluntarily provided input until the completion of the study.

\section{References}

Board of Studies, Teaching and Educational Standards NSW. (2012). Australian Professional Standards for Teachers. Retrieved from http://www.nswteachers.nsw.edu.au/publications-policies-resources/publications/australian-professional-sta ndards-for-teachers/

Chapman, T. \& Kinloch V. (2011). Emic Perspectives of Research. In D. Lapp. \& D. Fisher (Eds.), Handbook of research on teaching the English language arts (pp. 379-385). New York, NY: Routledge.

Coulacoglou, C. \& Saklofske, D. (2017). Psychometrics and psychological assessment. San Diego, CA: Academic Press.

Creswell, J. (1998). Qualitative inquiry and research design: Choosing among five traditions. London, UK: Sage.

Etzioni, A. (1969). Preface. In A. Etzioni (ed.). The semi-professions and their organization: teacher, nurses, social workers. New York, NY: The Free Press.

Evans, L. (2011). The 'shape' of teacher professionalism in England. British Educational Research Journal, 37, 851-870. https://doi.org/10.1080/01411926.2011.607231 
Evetts, J. (2011). The management of professionalism: a contemporary paradox. In S. Gewirtz, P. Mahony, I Hextall \& A. Cribb (Eds.), Changing teacher professionalism: International trends, challenges, and ways forward (pp.19-30). New York: Routledge.

Gitlin, A. \& Myers, B. (1993). Beth's story: The search for the mother/teacher. In D. McLaughlin \& W. Tierney (Eds.), Naming silenced lives: Personal narratives and the process of educational change (pp. 51-70). New York, NY: Routledge.

Gleeson, D. \& James, D. (2007). The paradox of professionalism in English Further Education: a TLC project perspective. Educational Review, 59, 451-467. https://doi.org/10.1080/00131910701619340

Goepel, J. (2012). Upholding public trust: an examination of teacher professionalism and the use of Teachers' Standards in England. Teacher Development, 16, 489-505. https://doi.org/10.1080/13664530.2012.729784.

Hargreaves, A. (2000). Four ages of professionalism and professional learning. Teachers and Teaching: Theory and Practice, 6(2). https://doi.org/10.1080/713698714

Hoyle, E. \& John, p. (1995). Professional knowledge and professional practice. London, UK: Cassell.

Hung, C. \& Li, F. (2017). Teacher Perceptions of professional role and innovative teaching at elementary schools in Taiwan. Academic Journals, 12(21), 1036-1045. https://doi.org/10.5897/ERR2017.3373

Kuhlman, N. \& Knezevic, B. (n.d.). The TESOL guidelines for developing EFL professional teaching standards. Alexandrai, VA: TESOL Press.

Popa, S. \& Acedo, C. (2006). Redefining professionalism: Romanian secondary education teachers and the private tutoring system. International Journal of Educational Development, 26, 98-110. https://doi.org/10.1016/j.ijedudev.2005.07.019

Richards, J., Gallo, P. \& Renandya, W. (2001). Exploring teachers' beliefs and the processes of change. PAC Journal, 1(1), 41-58.

Shulman, L. (1987). Knowledge and teaching: Foundations of the new reform. Harvard Educational Review, 57, 1-22. https://doi.org/10.17763/haer.57.1.j463w79r56455411

Strauss, A. \& Corbin, J. (1990). Basics of qualitative research: Grounded theory procedures and techniques. Newbury Park, CA: Sage

Stronge, J. (2002). Qualities of effective teachers. Alexandria, VA: Association for Supervision and Curriculum Development.

Stronge, J. \& Tucker, P. (2000). Teacher evaluation and student assessment (NEA Student Assessment Series). Washington, DC: National Education Association.

Swann, M., McIntyre, D., Pell, T., Hargreaves, L. \& Cunningham, M. (2010). Teachers' conceptions of teacher professionalism in England in 2003 and 2006. British Educational Research Journal, 36, 549-571. https://doi.org/10.1080/01411920903018083

Tichenor, M. \& Tichenor, J. (2005). Understanding Teachers' Perspectives on Professionalism. The Professional Educator, 17(1-2), 89-95. Retrieved from https://files.eric.ed.gov/fulltext/EJ728484.pdf

Torres-Rocha, J.C. (2019). EFL Teacher Professionalism and Identity: Between Local/Global ELT Tensions. How Journal, 26(1), 153-176. https://doi.org/10.19183/how.26.1.501

\section{Copyrights}

Copyright for this article is retained by the author(s), with first publication rights granted to the journal.

This is an open-access article distributed under the terms and conditions of the Creative Commons Attribution license (http://creativecommons.org/licenses/by/4.0/). 